\title{
New species of Juncus (Juncaceae) in eastern Australia
}

\author{
L.A.S. Johnson
}

\begin{abstract}
Johnson, L.A.S. (National Herbarium of New South Wales, Royal Botanic Gardens, Sydney, NSW Australia 2000) 1993. New species of Juncus (Juncaceae) in eastern Australia. Telopea 5(2): 309-318. The following new species from eastern Australia are here described: Juncus brevibracteus, J. dolichanthus, J. firmus, J. mollis, J. ochrocoleus, J. phaeanthus, J. psammophilus, J. remotiflorus, J. semisolidus, and J. subglaucus.
\end{abstract}

\section{Introduction}

The revision of Australasian members of the genus Juncus currently being completed will not be published in time for the names of new species to be available for use in the forthcoming Flora of New South Wales vol. 4 and Flora of Victoria. Hence the relevant new species are published here. They will be treated more fully in the revision.

All of these species belong to the subgenus Genuini Buchenau, which is bestdeveloped in Australia. This is a difficult group taxonomically since the species appear to form a network of relationships. Many of the species hybridise freely when they come in contact with other species of the group, as has also been found with European species of this subgenus (Agnew 1968, Nilsson \& Snogerup 1971, Stace 1972, 1975).

Discrimination of species in this subgenus has depended on study of the culm anatomy as much as on exomorphological features. In some cases, especially with poorly developed individuals or incomplete specimens, certain identification of specimens is only possible by examining culm cross-sections. The anatomy will be discussed in the revision. Measurement of culm diameter has been made about halfway along the length of the culm, as have counts of number of vertical striations and assessment of whether the pith is continuous or interrupted. Culm hardness is also assessed at that point; culms are often softer near their apex than their base. Leaves are reduced to cataphylls, which are more or less uniformly straw-coloured near the apex in all species, hence description of cataphyll colour refers to the middle and basal portions.

\section{J. brevibracteus L.A.S. Johnson, sp. nov.}

Affinis J. proceri, ab hoc habitu graciliori, bractea inflorescentiae infima culmiformi brevi, floribus minoribus, differt.

TYPE: NEw SOUTH WALES: Southern Tablelands: Snubba Range, $14 \mathrm{~km}$ direct NE of Tumbarumba, L. Johnson 8274, 17 May 1976; holo NSW; iso CANB, CHR, K, MEL, NY.

Strongly rhizomatous perennial. Culms terete, \pm hard, mid-green, $45-125 \mathrm{~cm}$ long, 2.1-4.0 mm diam.; culm striations 45-110; pith finely interrupted. Cataphylls 8-19 cm long, lax, abaxially dark yellow-brown to orange-brown or dark red-brown at base, adaxially copper-coloured. Inflorescence $3-10 \mathrm{~cm}$ long, head-like or diffuse, with 
numerous flowers loosely to densely clustered at the apex of the branches; lowest inflorescence bract 4-16 cm long, slightly shorter than to slightly exceeding inflorescence, rarely exceeding it by more than $1 / 3$ of its length. Tepals straw-brown, often with darker bands; outer tepals 1.5-2.2 mm long, exceeding inner tepals, acute to acuminate, with narrow hyaline margins; inner tepals acute to obtuse, with broad hyaline margins. Stamens 3, shorter than outer tepals; anthers $0.4-0.7 \mathrm{~mm}$ long, $\geq$ filament length. Capsule exceeding outer tepals, ovate to elliptic, dark golden brown, often red-brown towards apex, shining, smooth, obtuse to broad-acute, not or scarcely apiculate. Seeds $0.4-0.6 \mathrm{~mm}$ long.

DistRiBUtion AND haBitAT: Higher-altitude (including lower subalpine) areas of southern New South Wales (including the A.C.T.) south from the Brindabella Range and north-eastern Victoria. Commonly around sphagnum bogs and along boggy creeks.

Notes: This species has been referred to as 'Juncus sp. I' since my early investigations of the genus, and is referred to in that way by Burbidge \& Gray (1970: 97). It is related to J. procerus E. Meyer, differing from that species in its more slender habit, its generally shorter flowers, and in its lowest inflorescence bract being usually shorter than the inflorescence it subtends. It grows at higher altitudes than J. procerus.

DeRIVATION OF EPITHET: From the Latin brevis, short, and bractea, a bract (in botanical usage), referring to the lowest inflorescence bract and also the second bract, both of which are shorter than in the related J. procerus.

SELECTED SPECIMENS: VICTORIA: East Gippsland: Upper Delegate River, near Bidwell, Melville 2947, Wakefield $\mathcal{E}$ Hunter, Jan 1953 (K, NSW). Snowfields: Bluff Hut area, c. 10 miles [16 km] SW of Mt Speculation, Beauglehole 43515, Nov 1973 (MEL, NSW).

\section{J. dolichanthus L.A.S. Johnson, sp. nov.}

Affinis J. radulae J. remotifloroque, ab altero culmis non scaberulis, capsula breviore, ab altero medulla saepissime continua, antheris longioribus, bractea inflorescentiae infima plerumque quam inflorescentia longiore, striis plerumque paucis, differt.

Type: New South WALES: North Western Plains: W of Cuttabri, K.L. Wilson 749, L.A.S. Johnson $\mathcal{E}$ S.W.L. Jacobs, 17 Nov 1974; holo NSW; iso BRI, CANB, CHR, K, MO, NY.

Slender rhizomatous perennial. Culms terete, \pm hard (softer above in big culms), greygreen, 30-60 cm long, 0.9-1.7 mm diam.; culm striations 22-35; pith continuous with occasional interruptions in upper half of culm. Cataphylls 5-8 cm long, \pm tight, abaxially golden brown to dark yellow-brown or rarely red-brown at base, adaxially silvery. Inflorescence $4-11 \mathrm{~cm}$ long, diffuse, with numerous solitary flowers spread evenly along the non-flexuose branches; lowest inflorescence bract $5-18 \mathrm{~cm}$ long, exceeding to slightly shorter than inflorescence. Tepals straw-brown, often tinged red-brown; outer tepals 2.9-3.1 mm long, $\geq$ inner tepals, acute to acuminate or mucronate, with \pm broad hyaline margins; inner tepals acute, with broad hyaline margins. Stamens 6 (rarely 3-5), shorter than outer tepals; anthers $0.5-1.0 \mathrm{~mm}$ long, $\geq$ filament length. Capsule shorter than to slightly exceeding outer tepals, elliptic to ovate, golden brown to dark golden brown, shining, smooth, obtuse, not or scarcely apiculate. Seeds $0.3-0.4 \mathrm{~mm}$ long.

DISTRIBUTION AND HABITAT: New South Wales; apparently restricted to the north-western edge of the Pilliga Scrub, where it is known from only three localities. Grows on sandy soils in shallow floodways.

Notes: This species has been referred to as 'Juncus sp. $Y^{\prime}$. It is similar to J. radula Buchenau and J. remotiflorus L.A.S. Johnson in habit and inflorescence form. It differs from the former in having a shorter capsule and smooth culms and inflorescence 
branches. From the latter, it differs in having mostly continuous pith in the culms, in having longer anthers, and in having the lowest inflorescence bract generally exceeding the inflorescence.

DERIVATION OF EPITHET: From the Greek dolichos, long, and anthos, a flower, referring to the long flowers compared with those of many other species in subgenus Genuini.

\section{J. firmus L.A.S. Johnson, sp. nov.}

Affinis $J$. continui J. alexandrique, ab his culmis subglaucis, cataphyllis basi atris, stomatibus in foveis minime profundis dispositis, differt.

TYPE: New SOUTH Wales: North Western Slopes: $41.5 \mathrm{~km} \mathrm{~S}$ of Tamworth on highway, K. Hill $1272 \mathcal{E}$ L. Johnson, 9 Sep 1985; holo NSW; iso CHR, K.

Strongly rhizomatous perennial. Culms terete, \pm hard, blue-green, subglaucous, $55-110 \mathrm{~cm}$ long, $2.2-5.0 \mathrm{~mm}$ diam.; culm striations 45-80; pith continuous or rarely slightly interrupted below. Cataphylls $9-27 \mathrm{~cm}, \pm$ lax, abaxially dark yellow-brown to dark red-brown or black (at very base only), adaxially silvery to dark golden brown. Inflorescence (4-)9-17 cm long, diffuse, with numerous solitary flowers spread along the non-flexuose branches or loosely to densely clustered at the apex of the branches; lowest inflorescence bract $12-25 \mathrm{~cm}$ long, exceeding inflorescence. Tepals acute to acuminate, straw-brown, with narrow to \pm broad hyaline margins; outer tepals 1.5-2.1 mm long, $\geq$ inner tepals. Stamens 3, shorter than outer tepals; anthers $0.4-0.7$ $\mathrm{mm}$ long, equalling or occasionally slightly longer than filaments. Capsule exceeding outer tepals, elliptic, golden brown, shining, smooth, broad-acute to obtuse, not or scarcely apiculate. Seeds $0.3-0.5 \mathrm{~mm}$ long.

Distribution AND habitat: Queensland and New South Wales; from Jimbour (Darling Downs) south along the Western Slopes and western edge of the Tablelands to near Bathurst, extending east to the dryish parts of the North Coast ranges near Curricabark. It occurs mostly at lower altitudes than $J$. alexandri, on basic soils in seasonally wet situations; not common.

Notes: This species has been referred to as 'Juncus sp. D2' for many years. It differs from J. continuus L.A.S. Johnson, J. alexandri L.A.S. Johnson and J. laeviusculus L.A.S. Johnson in having subglaucous culms, with the stomates slightly sunken, and generally darker cataphylls. It generally occurs at lower altitudes than the latter two species and on heavier soils than J. continuus.

DERIVATION OF EPITHET: From the Latin firmus, strong, referring to the firm culms, which are not easily compressed between the fingers.

Selected sPeCimens: QueEnSLAND: Darling Downs: Jimba [=Jimbour], plains of the Condamine, Leichhardt, Nov 1843 (MEL 68031). New SOUTH WALES: North Coast: c. $3 \mathrm{~km}$ E of Curricabark, Johnson 7627, Coveny \& Jacobs, Mar 1973 (NSW, AD, BRI, CANB, CHR, HO, K, MEL). Northern Tablelands: S side of Crawney Pass, Wilson 855, Johnson $\mathcal{E}$ Jacobs, Nov 1974 (NSW). Central Tablelands: The Lagoon, c. 7.5 miles [12 km] S of Bathurst, Constable 4765b, Mar 1964 (NSW 70773, CBG, CHR, K, MEL). Central Western Slopes: Head of Coulsons Creek, c. $32 \mathrm{~km} \mathrm{~N}$ of Merriwa, Briggs $3454 \mathcal{E}$ Johnson, Mar 1970 (NSW).

\section{J. mollis L.A.S. Johnson, sp. nov.}

Affinis $J$. polyanthemi, ab hoc culmis haud glaucis mollioribusque medulla maxime interrupta, cellulis epidermalibus supra sclerenchymate quam eis supra chlorenchymate radialiter valde brevioribus, differt.

TyPE: New SOUTH WALES: Central Coast: 1 mile [1.6 km] W of Warnervale, L.A.S. Johnson, 12 April 1964; holo NSW; iso BRI, CHR, K. 
Strongly rhizomatous perennial. Culms terete, soft, mid-green, $85-145 \mathrm{~cm}$ long, 2.1-4.0 mm in diam.; culm striations 38-70; pith very interrupted. Cataphylls $14-27 \mathrm{~cm}$ long, tight, abaxially yellow-brown to pink-brown to black at base, adaxially golden brown to copper-coloured or occasionally somewhat silvery. Inflorescence 7-15 cm long, diffuse, with numerous solitary flowers spread evenly along the branches; lowest inflorescence bract $15-30 \mathrm{~cm}$ long, exceeding inflorescence. Tepals straw-brown, with broad hyaline margins; outer tepals $1.7-2.2 \mathrm{~mm}$ long, $\geq$ inner tepals, acute to acuminate or mucronate; inner tepals acute. Stamens $3(-6)$, shorter than outer tepals; anthers $0.4-0.7 \mathrm{~mm}$ long, usually $\geq$ filament length. Capsule exceeding outer tepals, ovate to obovate, golden brown to dark golden brown, shining, smooth, obtuse, not or scarcely apiculate. Seeds $0.4-0.6 \mathrm{~mm}$ long.

Distribution and habitat: New South Wales; from Tumbulgum (North Coast) south along the coast to Bodalla (South Coast). Not recorded from Queensland but probably occurs near the State border in the Moreton District. Usually found in swamp forests, especially Melaleuca swamps, or occasionally in areas cleared from them, in very wet situations subject to seasonal drying-out. In contrast to J. polyanthemus and J. usitatus, with both of which it forms some hybrids in marginal situations, it does not survive well or tend to spread in cleared areas.

Notes: This species has been referred to as 'Juncus sp. $X^{\prime}$ for many years. It is related to J. polyanthemus Buchenau, but differs from that in its non-glaucous, more slender culms with very interrupted pith almost throughout their length, and in the epidermal cells over the sclerenchyma girders being radially smaller than those over the chlorenchyma (larger in J. polyanthemus). It differs from J. usitatus L.A.S. Johnson in the more numerous striations of its generally larger culms and its longer cataphylls, which clasp the culm more tightly and are less glossy. It also has the flowers more clustered and generally larger than in J. usitatus.

DERIVATION OF EPITHET: From the Latin mollis, soft, referring to the easily compressed culms.

Selected SPeCimens: New South Wales: North Coast: $2 \mathrm{~km} \mathrm{~W}$ of Wauchope, Johnson 8305, 26 Jan 1977 (NSW, CHR, K). South Coast: 7 km (4.4 miles) by road SE of Bodalla, Coveny 7317, Dec 1975 (NSW, CHR, K, MEL).

\section{J. ochrocoleus L.A.S. Johnson, sp. nov.}

Inter species subgeneris Genuini combinatione sequenti characterum distinguitur: culmi flavovirentes, medulla culmi lacunis amplis interrupta, stomatibus superficialibus; cataphylla laxe voluta, flavida vel aurea; inflorescentia diffusa; tepala $1.5-2.1 \mathrm{~mm}$ longa.

TYPE: NeW SOUTH WALES: North Western Slopes: 1 km SW of Binnaway, L.A.S. Johnson 7578 \& A.T. Johnson, 26 Feb 1973; holo NSW; iso K, MEL.

Strongly rhizomatous perennial. Culms terete, \pm hard, yellow-green, $35-85 \mathrm{~cm}$ long, 1.6-3.0 mm diam.; culm striations 20-52; pith finely interrupted. Cataphylls 7-15 cm long, \pm lax, abaxially pale yellow to pale golden brown, adaxially silvery to golden brown. Inflorescence 6-15 cm long, diffuse, with numerous solitary flowers spread evenly along the slightly flexuose branches; lowest inflorescence bract $7-20(-26) \mathrm{cm}$ long, exceeding to occasionally shorter than the inflorescence length. Tepals strawbrown; outer tepals $1.5-2.1 \mathrm{~mm}$ long, $\geq$ inner tepals, acute to acuminate, with \pm narrow hyaline margins; inner tepals acute, with broader hyaline margins. Stamens (3-) 4-6, shorter than outer tepals; anthers 0.4-0.8 mm long, $\geq$ filament length. Capsule exceeding outer tepals, elliptic, golden brown, shining, smooth, obtuse, not or scarcely apiculate. Seeds $0.3-0.5 \mathrm{~mm}$ long. 
Distribution AND HABITAT: Queensland and New South Wales; south from Eidsvold (Burnett District) along the Tablelands and Western Slopes to Gilgandra and Rylstone, extending nearer the coast in the Wollombi area, and extending west as far as Pilliga and the Warrumbungle Range. Introduced into Great Britain (one specimen seen) with wool shoddy, but probably not persisting there. Commonly grows on sandy soils.

Notes: This species has been referred to as 'Juncus sp. $\mathrm{H}^{\prime}$ ' for many years. It is not particularly close to any other species and is distinctive in its combination of features: yellow-green culms with well-interrupted pith and superficial stomates; its rather lax, pale yellowish cataphylls; and its rather diffuse inflorescence with the small flowers evenly spread along the branches.

DERIVATION OF EPITHET: From the Greek ochros, pale yellow, and coleus, a sheath, referring to the generally pale yellowish cataphylls. The epithet is stressed on the second syllable, not the third, in which the $e$ represents the Greek epsilon.

SELECTED SPECIMENS: QueENSLAND: Burnett: 13 km N of Eidsvold, Johnson 7135 \& Briggs, June 1971 (NSW). Darling Downs: Owens Scrub Road, $6 \mathrm{~km}$ NW of Leyburn towards Yandilla, Wilson 4227, Dec 1981 (NSW, BRI). New South WaLes: Central Coast: Howes Valley, near Howes Valley P.O., Johnson, Nov 1965 (NSW 91241). Northern Tablelands: $8.1 \mathrm{~km}$ (5 miles) by road NE of Tenterfield towards Clifton on Bruxner Highway, Coveny $6667 \&$ Hind, Aug 1975 (NSW, BRI, CANB, CHR, K, L). Central Western Slopes: Gundibri, 20 miles [32 km] W of Aberdeen, Hunter Valley, Story 6978, Nov 1959 (NSW). North Western Plains: SW outskirts of Narrabri, Constable, Dec 1961 (NSW 60311).

\section{J. phaeanthus L.A.S. Johnson, sp. nov.}

Affinis $J$. vaginati, ab hoc culmis mollibus, plus minusve tortis complanatisque, inflorescentia plus minusve globosa, tepalis brevioribus, capsula atrobrunnea, differt.

TYPe: New South Wales: Southern Tablelands: Diggers Creek, Kosciusko Plateau, $4950 \mathrm{ft}$ [1500 m], L.A.S. Johnson 8280, 17 May 1976; holo NSW; iso CANB, K.

Shortly to strongly rhizomatous perennial. Culms terete, \pm hard, mid-green, 30-100 $\mathrm{cm}$ long, $2.0-3.0 \mathrm{~mm}$ diam.; culm striations 35-60, prominent; pith continuous. Cataphyils 5-15 cm long, \pm lax, abaxially yellow to dark orange-brown at base, adaxially silvery to golden brown. Inflorescence $2-10 \mathrm{~cm}$ long, head-like to diffuse, with flowers densely clustered at the apex of the branches; lowest inflorescence bract 4-20 $\mathrm{cm}$ long, exceeding inflorescence. Tepals straw-brown with red-brown sides; outer tepals 2.0-2.9 mm long, exceeding inner tepals, acuminate to acute, with narrow hyaline margins; inner tepals acute, with \pm broad hyaline margins. Stamens 3 , rarely 4 or 5 , shorter than outer tepals; anthers $0.4-0.6 \mathrm{~mm}$ long, $\leq$ filament length. Capsule $\geq$ outer tepals, elliptic, red-brown to dark red-brown or occasionally dark golden brown, shining, smooth, broad-acute to obtuse, not or scarcely apiculate. Seeds $0.4-0.5$ $\mathrm{mm}$ long.

Distribution AND HABiTAT: New South Wales and Victoria; from Ebor (Northern Tablelands) south along the higher parts of the Tablelands to north-eastern Victoria. Commonly above $1200 \mathrm{~m}$, in wet situations.

Notes: This species has been referred to as 'Juncus sp. $F$ ' for many years. Although resembling J. vaginatus $\mathrm{R}$.Br. in prominent culm striations and uninterrupted pith, it differs in its softer culms, which are often rather twisted and compressed. Its inflorescence is reddish and, although usually smaller in overall size than in J. vaginatus, is made up of larger clusters of flowers; in addition, the tepals are not as obvious as in $J$. vaginatus since they do not exceed the capsule as they do in that species. 
DERIVATION OF EPITHET: From the Greek phaeos, dark, and anthos, a flower, referring to the usually dark reddish colour of the inflorescence.

Selected SPecimens: New South WALEs: Northern Tablelands: $1 \mathrm{~km} \mathrm{~W}$ of Oakey Creek, between Wollomombi and Jeogla, c. $65 \mathrm{~km}$ ESE of Armidale, Briggs 3234 \& Johnson, Mar 1970 (NSW). Central Tablelands: Boyd River Fire Trail, c. $3 \mathrm{~km}$ W of Kanangra Walls road towards Morong Creek crossing, Wilson 1705, Jan 1977 (NSW). VICTORIA: Eastern Highlands: c. 2 miles [3 km] NE of Lambs Gap, c. 1 mile [1.6 km] E of Maroka Hut, Maroka Range, c. 6 miles [10 km] E of Mt Wellington, Beauglehole 43485, Nov 1973 (MEL, NSW). Snowfields: Dinner Plain, $11 \mathrm{~km}$ SE of Mt Hotham, Wilson 2083, Feb 1979 (NSW, CHR, K, L, MEL). East Gippsland: Back Creek, near Bendoc, Wakefield 3065, Jan 1948 (NSW).

\section{J. psammophilus L.A.S. Johnson, sp. nov.}

$\mathrm{Ab}$ omnibus speciebus subgeneris Genuini (J. ingenti excepto) plantis dioicis differt. $\mathrm{Ab}$ J. ingenti habitu multo graciliori, stomatibus in foveis dispositis, differt.

TyPE: NEW SOUTH WALES: North Western Plains: Werah Creek, Wee Waa to Cuttabri, L.A.S. Johnson, 19 Dec 1966; \%; holo NSW 94671; iso BRI, CANB, CHR, K.

Strongly rhizomatous, dioecious perennial. Culms terete, \pm soft, yellow-green, $65-125$ cm long, 1.6-3.2 mm diam.; culm striations 35-60; pith continuous, often interrupted in lower half. Cataphylls $12-28 \mathrm{~cm}$ long, lax, abaxially golden brown to dark yellowbrown or occasionally dark red-brown at base, adaxially golden brown. Inflorescence $5-10 \mathrm{~cm}$ long, diffuse, with numerous solitary flowers spread evenly along the often slightly flexuose branches; lowest inflorescence bract 8-32 cm long, exceeding inflorescence. Tepals acute to acuminate, straw-brown or occasionally red-tinged, with broad hyaline to yellowish margins; outer tepals (1.3-)1.5-2.6 mm long, $\geq$ inner tepals. Stamens 6, shorter than outer tepals; anthers $0.7-0.9 \mathrm{~mm}$ long, much exceeding filament length; female flowers with 6 staminodes. Capsule shorter than to slightly exceeding outer tepals, elliptic to obovate, golden brown, shining, smooth, obtuse, not or scarcely apiculate. Seeds $0.4-0.5 \mathrm{~mm}$ long.

$2 n=$ c. 40 (B.G. Briggs, pers. comm.; voucher NSW 60306 , \&)

Distribution AND habitat: Queensland, New South Wales and Victoria; inland areas south from near Wandoan (Leichhardt District) to near Grenfell, extending east to near Torrington (Northern Tablelands) and west to Mungindi and Nyngan, with a disjunct occurrence in central Victoria, between Bendigo and Benalla. Found along creeks that have at least a surface layer of sand, or with sand sometimes overlain by clayey deposits.

Notes: This species has been referred to as 'Juncus sp. $Q$ ' for many years. It is one of only two dioecious species known in the genus in Australia (the other is J. ingens N.A. Wakefield). The female inflorescence is sometimes larger overall than the male, but the tepals of female flowers are often shorter than in male flowers (1.3-2.0 mm long versus $1.8-2.6 \mathrm{~mm}$ long). The culms have sunken stomates, unlike those of the majority of species.

Derivation of epithet: From the Greek psammos, sand, and phileo, I love, referring to the species' most common habitat.

SELECTED SPECIMENS: QUeFnSLAND: Darling Downs: $1.6 \mathrm{~km}$ by road SSW of Kogan towards Tara, Coveny 6788 \& Hind, Aug 1975 (Q; NSW, BRI, CHR, K). New SouTh Wales: Northern Tablelands: 3 miles [5 km] from Tent Hill on Torrington road, Wilson 816, Johnson \& Jacobs, Nov 1974 (Q; NSW). North Western Slopes: Etoo Creek, $2.5 \mathrm{~km} \mathrm{~W}$ of Gibbican Forest Road along Number 1 Break, Baradine State Forest, Wilson 2454 \& Waterhouse, Aug 1979 (Q; NSW). Central Western Slopes: Bogan River crossing, W of Tomingley on Tullamore road, Johnson 8466, May 1979 (ф; NSW, CHR, K). VICTORIA: Midlands: Bagshot North, at tributary of Reedy Creek, Wilson 
1035 \& Johnson, Feb 1975 (९) NSW, CHR, MEL), Wilson 1036 \& Johnson (ơ; NSW, BRI, CHR, MEL).

\section{J. remotiflorus L.A.S. Johnson, sp. nov.}

Affinis J. subsecundi, sed culmis mollibus, striis numerosioribus, inflorescentia majori floribus semper solitariis, differt. Similis J. radulae, ab hoc culmis rasilibus, medulla valde interrupta, striis numerosis, bractea inflorescentiae infima saepe quam inflorescentia breviora, differt.

Type: New South Wales: Central Western Slopes: western slopes of Hervey Range, W of Bumberry Creek, L.A.S. Johnson 8003 \& K.L. Wilson, 22 Feb 1975; holo NSW; iso K.

Slender, shortly rhizomatous perennial. Culms terete, very soft (often flattened and splitting when dry), grey-green to blue-green, occasionally waxy-glaucous, $15-70 \mathrm{~cm}$ long, 0.9-2.0(-2.7) $\mathrm{mm}$ diam.; culm striations 25-60; pith interrupted with large lacunae. Cataphylls 3-13 cm long, \pm tight, abaxially pale yellow to dark yellow-brown at base, adaxially silvery to golden brown. Inflorescence $7-19 \mathrm{~cm}$ long, diffuse, with numerous solitary flowers spread evenly and distantly along the non-flexuose branches; lowest inflorescence bract 3-20 cm long, shorter than to twice as long as inflorescence. Tepals acute to acuminate, straw-brown, often red-tinged, with \pm broad hyaline margins; outer tepals $2.5-3.5 \mathrm{~mm}$ long, $\geq$ inner tepals. Stamens 3-6, shorter than outer tepals; anthers $0.5-0.9 \mathrm{~mm}$ long, $\geq$ filament length. Capsule $\leq$ outer tepals, obovate to ovate, golden brown, smooth, shining, obtuse, not or scarcely apiculate. Seeds $0.3-0.4$ mm long.

Distribution AND HABITAT: Queensland, New South Wales and Victoria; from near Stanthorpe south (mainly on the Tablelands and Western Slopes but also in drier parts of the Coast) to central Victoria, extending to the Grampians and near Orbost. Commonly in only temporarily wet situations such as minor watercourses.

Notes: This species has been referred to as 'Juncus sp. $\mathrm{A}^{\prime}$ for many years. It is related to J. subsecundus N.A. Wakefield (and was included in Wakefield's concept), but differs in having a very soft (compressible) culm with pith that is more interrupted (scarcely more than traces present in some culms). It tends to have more striations and a larger inflorescence than $J$. subsecundus. The latter varies widely in the form of its inflorescence from (typically) having the flowers somewhat spread out along the branches to forms in which the flowers are quite clustered or are very widely spaced along the branches. The inflorescence of $J$. remotiflorus is most similar to that of the inland form of $J$. subsecundus (for some time referred to by me as Juncus sp. C) with very widely spaced flowers, from which it differs in the generally longer flowers (the tepals are mostly $2.5-3.0 \mathrm{~mm}$ long in that form of $J$. subsecundus) as well as in the culm characters. However, it should be noted that the flowers can be longer in the other forms of $J$. subsecundus, especially the form with rather clustered flowers in central to south-western Victoria (tepals to $4.0 \mathrm{~mm}$ long). J. remotiflorus superficially resembles $J$. radula Buchenau, another slender species that often has the flowers widely spread along the branches of the inflorescence. However, it differs from J. radula in not having finely scabrous culms and inflorescence parts. In addition, it has soft culms with very interrupted pith (continuous in J. radula) and more numerous striations. The lowest inflorescence bract is often shorter than the inflorescence but can range in the same specimen from that proportion to twice as long as the inflorescence. Hybrids with J. subsecundus are rather common in contact and colonised areas.

DERIVATION OF EPTTHET: From the Latin remotus, distant, and flos, floris, a flower, referring to the wide spacing of the flowers on the inflorescence branches. 
Selected SPecimens: QueensLAND: Darling Downs: $1.2 \mathrm{~km}$ SW of Dalveen railway station on Cottonvale road, Hill 1255 \& Johnson, Aug 1984 (NSW, BRI, MO). New SOUtH WaLes: North Coast: Millfield on the Cessnock-Wollombi road, Coveny 6491 \& Powell, Jun 1975 (NSW, BRI, CANB, CHR, NE, NT, NY). Central Coast: $3.2 \mathrm{~km}$ SW of Casula, Coveny 4349, Nov 1973 (NSW, CHR, K). South Coast: $5.6 \mathrm{~km} \mathrm{~S}$ of Nowra, Coveny 6175, Hind \& Hancock, Mar 1973 (NSW, CANB, CHR, K, L, LE, MEL, PERTH, RSA). Northern Tablelands: McIntyre River - Gwydir River Divide, NW of Moredun Creek (on Wandsworth-Tingha road), Johnson, May 1957 (NSW 41868). Central Tablelands: 6.5 miles [11 km] NE of Kelso on Limekilns road (NE of Bathurst), Constable 5594, Dec 1964 (NSW). Southern Tablelands: $9 \mathrm{~km} \mathrm{~S}$ of Bungonia on Tarago road, Johnson 8050, Mar 1975 (NSW). North Western Slopes: Etoo Creek, $2.5 \mathrm{~km}$ W of Gibbican Forest Road, along Number 1 Fire Break, Baradine State Forest, Wilson 2453 \& Waterhouse, Aug 1979 (NSW, CHR). South Western Slopes: Six Mile Reserve, Holbrook, McBarron 690, Mar 1947 (NSW). North Western Plains: Gravel pit 10 miles [16 km] SE of Narrabri on Boggabri road, Solling 537, Oct 1973 (NSW). South Western Plains: Spring Hill, Cocoparra National Park, c. 30 $\mathrm{km} \mathrm{NE}$ of Griffith, Johnston, Nov 1979 (NSW 257606, CANB). VICTORIA: Grampians: below W foot of Mt Stapylton, Wilson 1090 \& Johnson, Feb 1975 (NSW, HO, MEL). Midlands: W edge of Whipstick Forest Reserve on Neilborough East - Eaglehawk road, Wilson 1037 \& Johnson, Feb 1975 (NSW, AD, MEL). Riverina: Killawarra State Forest, $20 \mathrm{~km}$ NW of Wangaratta P.O., Beauglehole 64180, June 1979 (MEL, NSW). Eastern Highlands: $11 \mathrm{~km}$ NNE of Jamieson, Beauglehole 70768, Aug 1982 (MEL, NSW). East Gippsland: Rifle Range area, Orbost, Beauglehole 34556, Nov 1970 (MEL, NSW). Gippsland Plain: $6.5 \mathrm{~km}$ by road SE of Seaton on the SeatonHeyfield road, Albrecht 1928, Sep 1985 (MEL, NSW).

\section{J. semisolidus L.A.S. Johnson, sp. nov.}

Inter species subgeneris Genuini combinatione sequenti characterum distinguitur: habitus plus minusve robustus, culmi subglauci medulla plerumque continua sed saepe in medio parte interrupta, stomata in foveis minime profundis disposita, stamina 3.

TYPE: VICTORIA: Riverina: c. $2 \mathrm{~km} \mathrm{~S}$ of Wunghnu on Shepparton road, K.L. Wilson 1020 $\mathcal{E}$ L.A.S. Johnson, 15 Feb 1975; holo NSW; iso CHR, K, MEL.

Strongly rhizomatous perennial. Culms terete, \pm hard, grey-green, subglaucous, 90-160 cm long, 3.5-8.5 mm diam.; culm striations 60-120; pith continuous and interrupted in same culm. Cataphylls $10-36 \mathrm{~cm}$ long, lax, abaxially dark yellow-brown to dark red-brown or black towards base, adaxially silvery to golden brown. Inflorescence $10-25 \mathrm{~cm}$ long, diffuse, with numerous flowers loosely to densely clustered at the apex of the branches; lowest inflorescence bract $16-43 \mathrm{~cm}$ long, exceeding or occasionally equalling inflorescence. Tepals straw-brown, with broad hyaline margins; outer tepals (1.7-)2.0-2.7 mm long, $\geq$ inner tepals, acuminate to acute or mucronate, inner tepals acute. Stamens 3 or rarely 4 , shorter than outer tepals; anthers 0.4-0.9 mm long, generally $\geq$ filament length. Capsule equalling or slightly exceeding outer tepals, narrow-elliptic, golden brown, shining, smooth, obtuse, not or scarcely apiculate. Seeds $0.4-0.5 \mathrm{~mm}$ long.

DistRIBUTION AND HABITAT: New South Wales and Victoria; from Holbrook on the South Western Slopes along the Murray River valley west at least to the Mathoura area, extending south in the Midlands of Victoria to Maryborough. Usually found on clay soils in wet situations; not very common.

Notes: This species has been referred to as 'Juncus sp. $O$ ' for many years. It is a species of robust habit, not particularly close to any other. The culms have slightly sunken stomates and the pith is mostly continuous but often interrupted in the middle region of a culm. The flowers regularly have three stamens.

DeRIVATION OF EPITHET: From the Latin semi-, half, and solidus, solid, referring to the pith in the culms, which mostly varies within the one culm from continuous to interrupted. 
Selected SPeCimens: New South Wales: South Western Slopes: c. $5 \mathrm{~km}$ S of Jindera on Albury road, Wilson 1000 \& Johnson, Feb 1975 (NSW, CHR). South Western Plains: 38 km WNW of Strathmerton, Pressey, Apr 1984 (NSW 248699). VICTORIA: Midlands: Tarnagulla, Johnson 7744, Apr 1974 (NSW).

\section{J. subglaucus L.A.S. Johnson, sp. nov.}

Affinis J. aridicolae J. usitatique, sed ab altero culmis durioribus, ramulis inflorescentiae non flexuosis, ab altero culmis subglaucis, inflorescentia densiore, floribus saepe majoribus, et $\mathrm{ab}$ ambobus fasciculis sclerenchymatis majoribus, differt.

TyPE: New South WaLES: North Western Slopes: Ulinda Railway Station, c. 9 miles [14 kml SE of Binnaway, L.A.S. Johnson \& J. Pickard, 7 Apr 1970; holo NSW 105133; iso $\mathrm{BRI}, \mathrm{CHR}, \mathrm{K}, \mathrm{MO}, \mathrm{NY}$.

Strongly rhizomatous perennial. Culms terete, \pm hard, grey-green, \pm waxy-glaucous, 40-105 cm long, 1.4-2.3 mm diam.; culm striations 35-55; pith interrupted. Cataphylls 7-17 cm long, \pm lax, abaxially dark yellow-brown to red-brown or occasionally black at base, adaxially silvery to pale golden brown. Inflorescence $4-10(-15) \mathrm{cm}$ long, diffuse, with numerous flowers loosely to densely clustered at the apex of branches; lowest inflorescence bract $10-22 \mathrm{~cm}$ long, exceeding inflorescence. Tepals straw-brown, with broad hyaline margins; outer tepals $1.8-2.6 \mathrm{~mm}$ long, $\geq$ inner tepals, acute to acuminate or mucronate; inner tepals acute to acuminate. Stamens 3, shorter than outer tepals; anthers (0.2-)0.4-0.8 mm long, \pm equalling filament length. Capsule exceeding or rarely equalling outer tepals, obovate to elliptic, golden brown, shining, smooth, broad-acute to obtuse, not or scarcely apiculate. Seeds $0.3-0.4 \mathrm{~mm}$ long.

Distribution AND habiTAt: Queensland and New South Wales; scattered from Taroom (Leichhardt District) south (mainly on the Western Slopes and near Western Plains) to Grenfell (CWS) and Wakool (SWP), extending to the Tablelands near Torrington (NT) and Hill End (CT), closer to the coast in dryish areas in the Hunter Valley and near Kempsey. Found near permanent water and in seasonally wet situations such as roadside table-drains.

Notes: This species has been referred to as 'Juncus sp. U' for many years. It differs from J. aridicola L.A.S. Johnson in its harder culms (that is, less easy to compress between the fingers) with generally fewer and coarser striations, and in not having flexuose branches in the inflorescence. It differs from J. usitatus in having subglaucous, harder culms and a denser inflorescence with the flowers more clustered and generally somewhat larger. Hybrids are common with both of these species where their distributions meet, especially in places disturbed by human activity.

DERIVATION OF EPITHET: From the Latin sub-, somewhat, and glaucus, covered with a fine bloom, referring to the culm surface.

SelECTED SPECIMENS: QueENSLAND: Leichhardt: c. $3 \mathrm{~km} \mathrm{~N}$ of Robinson Creek, $\mathrm{N}$ of Taroom, Johnson $\mathcal{E}$ Blaxell 728, Nov 1972 (NSW). Darling Downs: 17 miles [27 km] ESE of Inglewood, near Bracker Creek, Johnson, Apr 1962 (NSW 57143). New SoutH WaLes: North Coast: SingletonBroke road, 1.6 miles [2.6 km] E of Nine Mile Creek, Johnson, Jan 1962 (NSW 60671). Northern Tablelands: 2.5 miles [4 km] from Tent Hill on Torrington road, Wilson 814, Johnson $\mathcal{E}$ Jacobs, Nov 1974 (NSW). Central Tablelands: Turon Lookout, Hill End, Johnson 8108, May 1975 (NSW). Central Western Slopes: Bruinbun, Macquarie River, $13 \mathrm{~km}$ direct SSE of Hill End, Johnson 8118, May 1975 (NSW, K). North Western Plains: Near Boppy Mountain on road to Girilambone, Moore 7575, Apr 1978 (NSW, CANB). South Western Plains: Conargo-Jerilderie road, over Forest Creek, McIntyre \& Newnham 492, Jan 1985 (NSW). 


\section{Acknowledgements}

While responsibility for the recognition of these species rests with myself, I most gratefully acknowledge collaboration by Karen L. Wilson over many years and, more recently, assistance in data compilation and other ways by Peter Bankoff. Many colleagues and collectors, especially Eddie McBarron, Robert Coveny, Cliff Beauglehole and the late Ernest Constable, have assisted in amassing field knowledge of the genus in Australia, and my family, particularly my sons Nicholas and Alexander Johnson, assisted me in collecting. The revision of Juncus in Australasia has recently been supported by two grants from the Australian Biological Resources Study.

\section{References}

Agnew, A.D.Q. (1968) The interspecific relationships of Juncus effusus and J. conglomeratus in Britain. Watsonia 6: 377-388.

Burbidge, N.T. \& Gray, M. (1970) Flora of the Australian Capital Territory (ANU Press: Canberra) Nilsson, O. \& Snogerup, S. (1971) Drawings of Scandinavian plants 45-64: Juncus L. Bot. Notiser 124: 1-8, 179-186, 311-316; 435-441.

Stace, C.A. (1972) The history and occurrence in Britain of hybrids in Juncus subgenus Genuini. Watsonia 9: 1-11.

Stace, C.A. (1975) Juncus. Pp. 461-467 in C.A. Stace (ed.), Hybridization and the flora of the British Isles (Academic Press: London).

Manuscript received 15 July 1992

Manuscript accepted 6 January 1993 